\title{
Effect of Some Agronomic Practices on Ascochyta Blight Severity and Yield of Faba Bean (Vicia faba L.) in Tunisia
}

\author{
A. Ouji $1^{1,2}$, S. Chekali ${ }^{1,3}$, M. Rouaissi ${ }^{4}$
}

10.18805/LR-637

\begin{abstract}
Background: In Tunisia, faba bean (Vicia faba L.) is the first major food legume. The development of faba bean production is facing several biotic constraints. Faba bean Ascochyta blight caused by Ascochyta fabae is one of the most destructive diseases of faba bean and can cause significant yield loss under favorable conditions. As only incomplete resistance ABL varieties are available, some agronomic practices should be applied to control and reduce Ascochyta blight incidence wherever possible. Therefore, this work was undertaken to evaluate the effect of spacing row and seed rate on $A B L$ severity, growth and yield of faba bean.

Methods: A split-plot design with three replications was adopted to carry out this study during 2018 and 2019 cropping seasons. 'Bachaar' faba bean variety was sown at 40 and $60 \mathrm{~cm}$ row spacing and at three seed rates $\left(100,140\right.$ and $\left.200 \mathrm{~kg} \mathrm{ha}^{-1}\right)$. ABL severity was assessed visually on a 0-9 scale and agro-morphological traits were measured. Analysis of variance was used to analyze the data. Correlations between agronomic traits, row spacing, seed rate and $A B L$ severity were investigated.

Result: Results showed that seed rate has a larger effect on yield than row spacing. In both cropping seasons, the highest grain yield was recorded in $60 \mathrm{~cm}$ row spacing and $140 \mathrm{~kg} \mathrm{ha}^{-1}$ seed rate treatment. So, this treatment is recommended for obtaining high yield of faba bean. Most of the variation in disease severity was associated with seed rate $(r=0.62)$. The highest $A B L$ score severity was noted at $200 \mathrm{~kg} \mathrm{ha}^{-1}$ rate. Over both years, wide row spacing and low seed rate reduced ABL severity. In this study, the small amounts of $A B L$ disease (which reached a score of 5.3 and 4.7 in 2018 and 2019, respectively) had little or no effect on yield.
\end{abstract}

Key words: Ascochyta fabae, Faba bean, Row spacing, Seed rate, Vicia faba L., Yield.

\section{INTRODUCTION}

Globally, faba bean (Vicia faba L.) is cultivated in $2.5 \mathrm{M}$. ha with a production of 4.5 million tons (FAOSTAT, 2019). As a legume, faba bean enhances the soil fertility by fixing atmospheric nitrogen in a wide range of conditions. Biological nitrogen fixation provides about $80 \%$ of the plant's nitrogen needs reaching $160 \mathrm{~kg} \mathrm{ha}^{-1}$ (Hauggaard et al., 2009). Faba bean serves as a valuable source of proteins (Alshameri et al., 2021) ranging from $24 \%$ to $35 \%$ (Crépon et al., 2010). The productivity of faba bean is constrained by various abiotic and biotic stresses. Among biotic stresses, Ascochyta blight, caused by Ascochyta fabae is one of the most destructive diseases of faba bean in Tunisia and can cause upto $35 \%$ yield loss under favorable conditions (Kharrat et al. 2006). In the absence of faba bean variety totally resistant to $A B L$, some methods have been used to control and reduce $A B L$ disease effects. The development of integrated disease management options (application of fungicides, crop rotation, use of resistant varieties, sowing date, row spacing and seeding rate) considerably reduces Ascochyta blight infection and are crucial for it's successful control (Ahmed et al., 2016). Furthermore, plant spacing in the field facilitate aeration and light penetration into plant canopy and optimize rate of photosynthesis as confirmed by Ugwuoke et al. (2021). Optimum spacing can ensure proper growth of the aerial and underground parts of the plant through efficient utilization of solar radiation, nutrients, water, land as well as air spaces and therefore contribute to
${ }^{1}$ Regional Research/Development Office of Agriculture in Northwest Semi-arid, le kef, Jendouba University, Tunisia.

${ }^{2}$ Field Crop Laboratory, National Institute for Agricultural Research of Tunisia, Ariana, Carthage University, Tunisia.

${ }^{3}$ Plant Protection Laboratory, National Institute for Agricultural Research of Tunisia, Ariana, Carthage University, Tunisia.

${ }^{4}$ Laboratory of Applied Plant Biotechnology, National Institute for Agricultural Research of Tunisia, Ariana, Carthage University, Tunisia.

Corresponding Author: A. Ouji, Field Crop Laboratory, National Institute for Agricultural Research of Tunisia, Ariana, Carthage University, Tunisia. Email: ali_ouji@yahoo.fr

How to cite this article: Ouji, A., Chekali, S. and Rouaissi, M. (2022). Effect of Some Agronomic Practices on Ascochyta Blight Severity and Yield of Faba Bean (Vicia faba L.) in Tunisia. Legume Research. 45(1): 58-62. DOI: 10.18805/LR-637.

Submitted: 09-06-2021 Accepted: 18-08-2021 Online: 09-09-2021

the increased yield as confirmed by Malik and Singh, (1996). Lopez-Bellido et al. (2005) reported that plant density can affect canopy development, radiation interception, drymatter production and evaporation of water from the soil under the crop, weed competition, the development of fungal and viral diseases, podding and harvesting height and eventually, seed yield. In Tunisia, in the absence of faba bean variety totally resistance to $A B L$, row spacing and seed rates methods should be used to control and reduce $A B L$ disease effects and help for the disease management of faba bean. 


\section{MATERIALS AND METHODS}

\section{Experimental procedure}

The experiment was conducted on farm field in Beldiya, Bousalem region over 2017/2018 and 2018/2019 cropping seasons under rainfed conditions. The area is situated in Jendouba governorate which is located in the northwest of Tunisia. For both cropping seasons, the maximum and minimum temperatures and rainfall are presented in Fig 1 and Fig 2. The treatments consisted of two raw spacing (40 and $60 \mathrm{~cm})$ and three seed rates $\left(100,140\right.$ and $\left.200 \mathrm{~kg} \mathrm{ha}^{-1}\right)$. 'Bachaar' faba bean variety, was planted in a in a split-plot design with three replications. Main plots consisted of row spacing and subplots as seed rate. Each row was $4 \mathrm{~m}$ long. Ascochyta blight severity ( $A B L)$ was assessed visually on a $0-9$ scale, where: $0=$ no infection, $1=1-9 \%$ of foliage area affected per plot, $2=10-19 \%, 3=20-29 \%, 4=30-39 \%, 5=$ $40-49 \%, 6=50-59 \%, 7=60-69 \%, 8=70-79 \%$ and $9=\geq 80 \%$ of the foliage area affected per plot. At full maturity, plant height (grain yield per ha $\left(\mathrm{GYha}^{-1}\right)$ and biological yield per ha $\left(\mathrm{BYha}^{-1}\right)$ were measured.

\section{Data analysis}

Data regarding $A B L$ severity and agro-morphological traits were subjected to ANOVA using statistix 8.1 computer software. Correlations between traits, row spacing, seed rate and $A B L$ severity were investigated using simple correlation coefficients.

\section{RESULTS AND DISCUSSION}

Impact of row spacing and seed rate on growth and yield of faba bean

\section{Plant height}

In both 2018 and 2019 cropping seasons, the analysis of variance of plant height indicated that seed rate and row spacing had a significant effect on plant height of faba bean (Table 1). Results inferred that plant height increased with increasing seed rate and decreasing row spacing (Table 2). Maximum plant height was recorded under $40 \mathrm{~cm}$ row spacing (105.8 and $108.1 \mathrm{~cm}$ in 2018 and 2019, respectively) and $200 \mathrm{~kg} \mathrm{ha}^{-1}$ seed rate $(127.7$ and $140.7 \mathrm{~cm}$ in 2018 and 2019 , respectively). The interaction effect of row spacing and seed rate was not significant on plant height of faba bean. The narrowest row spacing $(40 \mathrm{~cm})$ and highest seed rate $\left(200 \mathrm{~kg} \mathrm{ha}^{-1}\right)$ gave significantly taller plants (134.7 and $146 \mathrm{~cm}$, respectively) than the rest of the treatments. The increase in plant densities contribute to the increase of plant height. This was probably due to competition of plants in higher densities for light leading to taller stems, as well as the production of fewer tillers and develop longer internodes resulting in taller plants as confirmed by Singh et al. (2013).

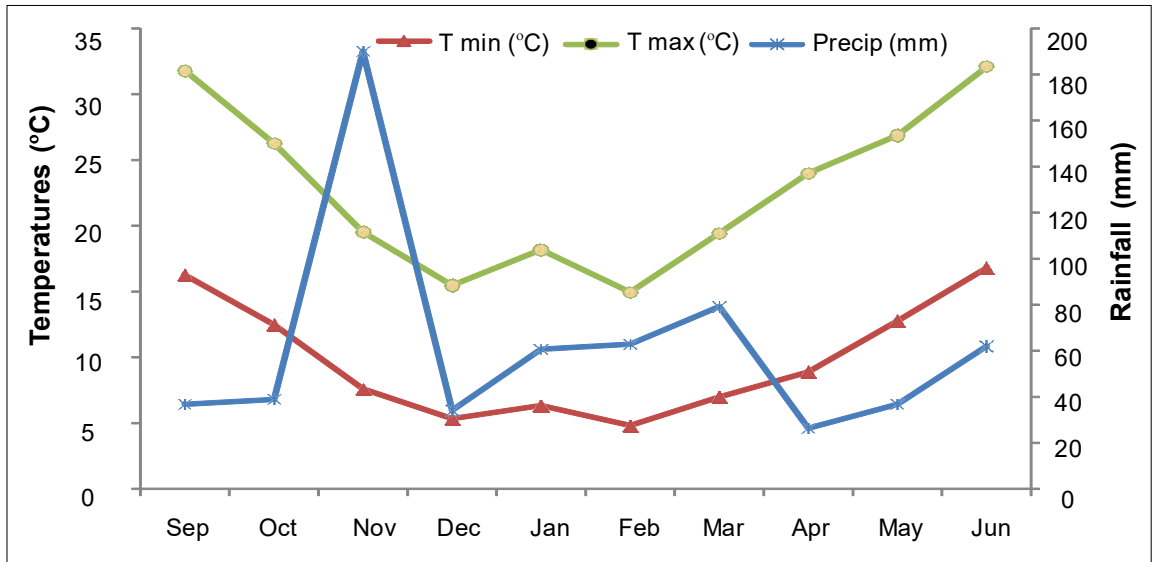

Fig 1: The maximum and minimum temperatures and rainfall recorded at Beldiya during 2017-2018 cropping season.

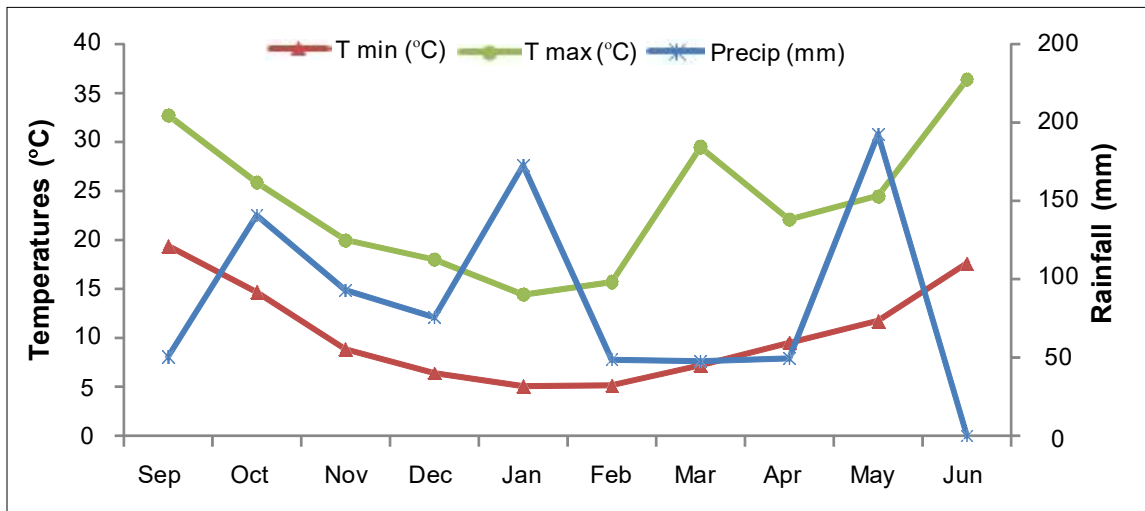

Fig 2: The maximum and minimum temperatures and rainfall recorded at Beldiya during 2018-2019 cropping season. 


\section{Biological yield}

Data given in Table 1 indicated that, in the first year, biological yield was influenced by seeding rate only.. But during the second year, both row spacing and seeding rate affected biological yield significantly. During the two years of study,viz., 2018 and 2019 cropping seasons, maximum biological yield was recorded at 140 (with 1952.5 and 2271.5 $\mathrm{kg} \mathrm{ha}^{-1}$ ) and $200 \mathrm{~kg} \mathrm{ha}^{-1}$ seed rate (with 1841.8 and 2079.7 $\mathrm{kg} \mathrm{ha}^{-1}$ ), respectively. Over 2018 and 2019, row spacing $\times$ seeding rate interaction effects on biological yields were not significant. However, $60 \mathrm{~cm}$ row spacing and $140 \mathrm{~kg} \mathrm{ha}^{-1}$ seed rate treatment was found to be the best for faba bean production in terms of biological yield per hectare (Table 2). This combination produced the highest biological yields 2053 and $2313 \mathrm{~kg} \mathrm{ha}^{-1}$ in 2018 and 2019, respectively. Biological yield was higher in high plant densities compared to low plant densities. This was due to the higher leaf area index which provided a larger surface area for light interception resulting in higher net photosynthesis and might have led to greater biomass per unit area as confirmed by Almaz and Kindie (2017). This result is in line with Al-Rifaee et al. (2004) who reported that the drymatter yield of faba bean increased with increasing plant population due to the increase in the number of plants per unit area and the associated increase in plant height. Similarly, biomass yield was justified by number of plant per unit area. Seeding rate also indirectly influences light interception, duration of vegetative growth, weed and disease control and finally grain quality (López-Bellido et al. 2005).

\section{Grain yield}

In both 2018 and 2019 cropping season, the analysis of variance of grain yield resulted in highly significant effects with seed rate (Table1). Analysis of variance did not show any significant effect on grain yield with row spacing and the row spacing $\times$ seeding rate interaction. The highest grain yield was registered under $140 \mathrm{~kg} \mathrm{ha}^{-1}$ seeding rate with 1806.5 and $2014.7 \mathrm{~kg} \mathrm{ha}^{-1}$ in 2018 and 2019 cropping seasons, respectively. Grain yield was tending to increase with increasing seed rates but at a density higher than optimal, grain yields decreased. Indeed, seed yield responded positively to an increase in seed rate up to about $140 \mathrm{~kg} \mathrm{ha}^{-1}$ and slightly decreased with $200 \mathrm{~kg} \mathrm{ha}^{-1}$. Results of Table 3 inferred that the increase in seed rate from 100 to $140 \mathrm{~kg} \mathrm{ha}^{-1}$ increased grain yield from 1427 to $1806.5 \mathrm{~kg} \mathrm{ha}^{-1}$ in 2018 and from 1513.2 to $2014.7 \mathrm{~kg} \mathrm{ha}^{-1}$ in 2019 . At 200 $\mathrm{kg} \mathrm{ha}^{-1}$ seed rate, grain yield decreased significantly. This extrapolation has been reported by Li et al. (2015) in corn (Zea mays L.) where the amount of drymatter accumulation and harvest index decreased with increasing seeding rate, although seed yield increased until an upper limit is reached and then began to decline. The influence of row spacing $x$ seed rate interaction on seed yield was not significant. However, the highest seed yield (1874 and $2050 \mathrm{~kg} \mathrm{ha}^{-1}$ registered in 2018 and 2019, respectively) was observed at $60 \mathrm{~cm}$ row spacing combined with $140 \mathrm{~kg} \mathrm{ha}^{-1}$ seed rate treatment. An optimum plant density ensures proper growth of the aerial and underground parts of the plant through efficient utilization of solar radiation, nutrients, land as well as air spaces and water as reported by Malek et al. (2012). As plant density per unit area increased there is more plant to plant competition which results in low nutrient partitioning into seeds as compared to straw; as a result there was low seed yield with low seed weights as confirmed by Kissi and Tamiru (2016).

Table 1: Analysis of variance with $F$ values of plant height $(\mathrm{PH})$, first pod level (FPL), grain yield (GY), biological yield (BY) and Ascochyta blight severity (ABL) over 2018 and 2019 cropping seasons.

\begin{tabular}{llcccrr}
\hline Year & Source of variation & PH & FPL & GY & BY & ABL \\
\hline \multirow{2}{*}{$2017-2018$} & Row spacing (RS) & $10000^{* *}$ & 4.23 & 0.82 & 2.56 & 3.57 \\
& Seeding rate (SR) & $18.40^{* *}$ & $22.77^{* *}$ & $6.93^{*}$ & $7.53^{*}$ & $11.20^{* *}$ \\
& RS $\times$ SR & 0.05 & 0.01 & 0.01 & 0.12 & 1.6 \\
$2018-2019$ & Row spacing (RS) & $387.77^{* *}$ & 0.01 & 1.10 & $18.71^{*}$ & 4 \\
& Seeding rate (SR) & $404.82^{* *}$ & $153.54^{* *}$ & $12.99^{* *}$ & $27.82^{* *}$ & $7.6^{*}$ \\
& RS $\times$ SR & 1.31 & $8.76^{* *}$ & 0.34 & 0.12 & 0.4 \\
\hline
\end{tabular}

Table 2: Means of plant height (PH) and biological yield (BY) under different row spacing and seeding rate over 2018 and 2019 cropping seasons.

\begin{tabular}{lccccccccc}
\hline & & \multicolumn{4}{c}{ Plant height $(\mathrm{PH})$} & \multicolumn{3}{c}{ Biological yields per ha (BY/ha) } \\
\cline { 3 - 10 } Year & Row spacing & \multicolumn{3}{c}{ Seed rates $\left(\mathrm{kg} \mathrm{ha}^{-1}\right)$} & \multicolumn{3}{c}{ Seed rates $\left(\mathrm{kg} \mathrm{ha}^{-1}\right)$} \\
\cline { 3 - 10 } & & 100 & 140 & 180 & Means & 100 & 140 & 180 & Means \\
\hline $2017-2018$ & $40(\mathrm{~cm})$ & 84 & 98.7 & 134.7 & $105.8 \mathrm{a}$ & 1322 & 1852 & 1724.3 & $1632.8 \mathrm{a}$ \\
& $60(\mathrm{~cm})$ & 75 & 88.3 & 120.7 & $94.7 \mathrm{~b}$ & 1643.3 & 2053 & 1959.3 & $1885.2 \mathrm{a}$ \\
& Means & $79.5 \mathrm{a}$ & $93.5 \mathrm{a}$ & $127.7 \mathrm{~b}$ & - & $1482.7 \mathrm{a}$ & $1952.5 \mathrm{~b}$ & $1841.8 \mathrm{~b}$ & - \\
$2018-2019$ & $40(\mathrm{~cm})$ & 79.7 & 98.7 & 146 & $108.1 \mathrm{a}$ & 1448.7 & 2230 & 2054 & $1910.9 \mathrm{a}$ \\
& $60(\mathrm{~cm})$ & 76 & 89.3 & 135.3 & $100.2 \mathrm{~b}$ & 1598.3 & 2313 & 2105.3 & $2005.6 \mathrm{~b}$ \\
& Means & $77.8 \mathrm{a}$ & $94 \mathrm{~b}$ & $140.7 \mathrm{c}$ & - & $1523.5 \mathrm{a}$ & $2271.5 \mathrm{~b}$ & $2079.7 \mathrm{~b}$ & - \\
\hline
\end{tabular}


Effect of Some Agronomic Practices on Ascochyta Blight Severity and Yield of Faba Bean (Vicia faba L.) in Tunisia

Table 3: Means of grain yield (GY) and Ascochyta blight severity (ABL) under different row spacing and seeding rate over 2018 and 2019 cropping seasons.

\begin{tabular}{|c|c|c|c|c|c|c|c|c|c|}
\hline \multirow{3}{*}{ Year } & \multirow{3}{*}{ Row spacing } & \multicolumn{4}{|c|}{ Grain yield (GY) } & \multicolumn{4}{|c|}{ Ascochyta blight severity (ABL score) } \\
\hline & & \multicolumn{4}{|c|}{ Seed rates $\left(\mathrm{kg} \mathrm{ha}^{-1}\right)$} & \multicolumn{4}{|c|}{ Seed rates $\left(\mathrm{kg} \mathrm{ha}^{-1}\right)$} \\
\hline & & 100 & 140 & 180 & Means & 100 & 140 & 180 & Means \\
\hline \multirow[t]{3}{*}{$2017-2018$} & $40(\mathrm{~cm})$ & 1372.3 & 1739 & 1407.3 & $1506.2 a$ & 3.67 & 4.33 & 6.33 & $4.78 a$ \\
\hline & $60(\mathrm{~cm})$ & 1481.7 & 1874 & 1553.3 & $1636.3 a$ & 3 & 3.67 & 4.33 & $3.67 a$ \\
\hline & Means & $1427 a$ & $1806.5 b$ & $1480.3 a$ & - & $3.33 a$ & $4 a$ & $5.33 b$ & - \\
\hline \multirow[t]{3}{*}{ 2018-2019 } & $40(\mathrm{~cm})$ & 1543.3 & 1979.3 & 1600.3 & $1707.7 a$ & 3 & 4.33 & 5 & $4.11 a$ \\
\hline & $60(\mathrm{~cm})$ & 1483 & 2050 & 1696 & $1743 a$ & 3 & 3.67 & 4.33 & $3.67 a$ \\
\hline & Means & $1513.2 a$ & $2014.7 b$ & $1648.2 \mathrm{a}$ & - & $3 a$ & $4 b$ & $4.67 b$ & - \\
\hline
\end{tabular}

Impact of row spacing and seeding rate on Ascochyta blight severity

The analysis of variance of ascochyta blight severity showed a significant effect of seed rate in 2018 and 2019 cropping seasons. Over both the years, the effect of row spacing and row spacing $\times$ seed rate interaction were not significant (Table 1). Results of Table 3 showed that the increase in seed rate from 100, 140 and $200 \mathrm{~kg} \mathrm{ha}^{-1}$ increased Ascochyta blight severity. Ascochyta blight severity was lower at 100 $\mathrm{kg} \mathrm{ha}^{-1}$ seeding rate (mean score of 3.33 and mean score of 3 in 2018 and 2019, respectively), compared to the highest severity of Ascochyta blight (mean score 5.33 and mean score 4.67) that was scored at $200 \mathrm{~kg} \mathrm{ha}^{-1}$ seed rate. Reduced plant population density could be one tool in a program to manage Ascochyta blight of faba bean. Decreasing disease severity level of faba bean observed with $100 \mathrm{~kg} \mathrm{ha}^{-1}$ seed rate could be due to proper aeration resulting in decreased humidity level suitable for fungus growth and decreasing plant population also limits the transmission of rust pathogen to the next plant as confirmed by Mengesha and Tesfaye, (2015). Disease incidence and severity tended to increase with increased plant spacing in susceptible cultivars as confirmed by Maasa et al. (2006). Tala and Shalaldeh (2006) reported that lowering plant density reduced the risk and pressure of diseases such as chocolate spot and Ascochyta blight. In Tunisia, Ascochyta blight disease is among the major constraint to yield improvement and adoption of the crop by farmers which cause complete yield loss. Since only faba bean are susceptible to Aschochyta blight, cultural practices such as optimum seed rate and row spacing could be able to control this disease as confirmed by Kimurto et al. (2013).

\section{Correlation among disease severity and yield and related} traits

The objective of this study was to evaluate the effect of some cultural practices on yield and disease development. The level of association among disease severity and yield and related traits could be helpful for the achievement of the highest yield and determining the suitable row spacing and seed rate to decrease diseases severity. Results showed that Ascochyta blight ( $A B L)$ severity was significantly $(p \leq 0.01)$ and positively correlated with seed rate $(r=0.62)$
Table 4: Coefficients of correlation between $A B L$ severity, plant height $(\mathrm{PH})$, first pod level $(\mathrm{FPL})$, grain yield $(\mathrm{GY})$, biological yield (BY), row spacing and seeding rate.

\begin{tabular}{lccccc}
\hline & RS & SR & PH & GY & BY \\
\hline SR & - & 1 & & & \\
PH & -0.19 & $0.89^{* *}$ & 1 & & \\
GY & 0.16 & 0.15 & -0.05 & 1 & \\
BY & 0.26 & $0.55^{* *}$ & $\mathbf{0 . 3 5}^{*}$ & $\mathbf{0 . 8 7 ^ { * * }}$ & 1 \\
ABL & -0.32 & $\mathbf{0 . 6 2}^{* *}$ & $0.61^{* *}$ & -0.22 & 0.07 \\
\hline
\end{tabular}

and plant height ( $r=0.61)$ (Table 4). It is known that plant diseases impose significant yield losses. In this study, ABL severity was not correlated with grain and biological yields. Consequently, $A B L$ attacks had no negative impact on yields. Our results are consistent with those found by McGrath, (2004), who reported that small amounts of ABL disease have little or no effect on yield and the disease may not be worth controlling. Biological yield was positively correlated with seeding rate $(r=0.55)$, plant height $(r=0.35)$ and grain yield ( $r=0.87$ ). It is usually not sufficient to determine whether a disease is present or absent. The critical information required is the amount of disease that is present. Disease often has to exceed a certain threshold before it reduces the yield of a crop.

\section{CONCLUSION}

The present study demonstrated that besides genetic constitution, row spacing and seed rate also control growth performance of faba bean. Seed rate has a larger effect on yield than row spacing. The highest grain yield was recorded in $60 \mathrm{~cm}$ row spacing and $140 \mathrm{~kg} \mathrm{ha}^{-1}$ seeding rate treatment. So, this treatment is recommended for obtaining high grain yield. In this study, ABL attacks have little or no effect on faba bean yields because the small amounts of disease. However, low seeding rate could reduce the Ascochyta blight severity. Therefore, decreasing density could be one tool to manage Ascochyta blight of faba bean. The choice of row spacing and seed rate should be considered as important components of integrated pest management and reduce Ascochyta blight pressure wherever possible in faba bean. Since this research is done in one location, research works should be carried out for confirmation in different location in the future. 


\section{REFERENCES}

Ahmed, K.S., Abang, M., Maalouf, F. (2016). Integrated management of Ascochyta blight (Didymella fabae) on faba bean under Mediterranean conditions. Crop Protection. 81: 65-69.

Almaz, M.G., Tesfaye, K. (2017). Optimum inter and intra row spacing for faba bean production under Fluvisols. Mayfeb, Journal of Agricultural Science. 4: 10-19.

Al-Rifaee, M.O.H.D., Turk, M.A., Tawaha A.R.M. (2004). Effect of seed size and plant population density on yield and yield components of local fababean (Vicia faba L.). International Journal of Agriculture and Biology. 6: 294-299.

Alshameri, A.M., Alghamdi, S.S., Gaafar, A.Z., Almunqedhi, B.M., Qahtan, A.A., Hodhod, M.S. and Migdadi, H.M. (2021). Effect of water deficit on yield of different faba bean (Vicia faba L.) genotypes. Legume Research. 44: 718-722.

Crépon, K., Marget, P., Peyronnet, C., Carrouee, B., Arese, P., Duc, G. (2010). Nutritional value of faba bean (Vicia faba L.) seeds for feed and food. Field Crops Res. 115: 329-339.

Food and Agriculture Organization of the United Nations (2019). FAOSTAT. Available online: http://faostat.fao.org.

Hauggaard-Nielsen, H., Mundus, S., Jensen, E.S. (2009). Nitrogen dynamics following grain legumes and subsequent catch crops and the effects on succeeding cereal crops. Nutrient Cycling in Agroecosystems. 84: 281-291.

Kharrat, M., Le Guen, J., Tivoli, B. (2006). Genetics of resistance to 3 isolates of Ascochyta fabae on faba bean (Vicia faba L.) in controlled conditions. Euphytica. 151: 49-61.

Kimurto, P.K., Towett, B.K., Mulwa, R.S., Njogu, N., Jeptanui, L.J., Rao, G.N., Silim, S., Kaloki, P., Korir, P., Macharia J.K. (2013). Evaluation of chickpea genotypes for resistance to Ascochyta blight (Ascochyta rabiel) disease in the dry highlands of Kenya. Phytopathologia Mediterranea. 52: 212-221.

Kissi, W., Tamiru, M. (2016). Effect of sowing method and seed rate on the growth, yield and yield components of faba bean (Vicia faba L.) under highland conditions of Bale, Southeastern Ethiopia. Research Journal of Agriculture and Environmental Management. 5(3): 86-94.
Li, J., Xie, R.Z., Wang, K.R., Ming, B., Guo, Y.Q., Zhang, G.Q., Li, S.K. (2015). Variations in maize dry matter, harvest index and grain yield with plant density. Agronomy Journal. 107: 829-834.

Lopez-Bellido, F.J., Lopez-Bellido, L., Lopez-Bellido R.J. (2005). Competition, growth and yield of faba bean (Vicia faba L.). European Journal of Agronomy. 23: 359-378.

Maasa, L.A., Dashiellb,K.E., Meloukc, H.A. (2006). Planting density influences disease incidence and severity of sclerotinia blight in peanut. Crop Sciences Journal. 46: 1341-1345.

Malek, M.A., Shafiquzzaman, M., Rahman, M.S., Ismail, M.R., Mondal, M.M.A. (2012) Standardization of soybean row spacing based on morpho physiological characters. Legume Research. 35: 138-143.

Malik, B.P.S., Singh, R.C. (1996). The influence of seeding rate and weed control in small seeded lentils (Lens culinaris). Weed Science. 45(2): 296-300.

McGrath, M.T. (2004). What are Fungicides? The Plant Health Instructor. DOI: 10.1094/PHI-I-2004-0825-01.

Mengesha, W., Tesfaye, A. (2015). Effect of spacing in incidence and severity of garlic rust [Puccinia allii (Rudolphi.)] and bulb yield and related traits of garlic at eastern Ethiopia. Journal of Plant Pathology and Microbiology. 6: 314.

Singh, A.K., Bhatt, B.P., Sundaram, P.K., Gupta A.K., Singh, D., (2013). Planting geometry to optimize growth and productivity in faba bean (Vicia faba L.) and soil fertility. Journal of Environmental Biology. 34(1): pp. 117.

Talal, T., Shalaldeh, G. (2006). Effect of planting date on faba bean Plant nodulation and performance under semi-arid conditions. World Journal of Agricultural Sciences. 2(4): 477-482.

Ugwuoke, C.U., Asogwa, A.A., Okwo, C.R., Onu, F.M., Eze, G.E. and Onah, F.C. (2021). Effects of planting distance and seed rate on the growth and yield of Egusi Melon (Citrullus colocynthis). Legume Research. 44(3): 328-333. 